\title{
Poverty Effectiveness for the Maisir (Contest) in the City of Indonesian Aceh Province
}

Siti Sahara and Meta Suriyani

\author{
Faculty of Law, University of Samudra, Langsa, Aceh, Indonesia
}

\begin{abstract}
Purpose - The purpose of this paper is to provide historical and current records about the state of Uqubat Hudud and/or Ta'zir against any person who performs gambling deeds that are in fact perceived to be ineffective in its implementation in Langsa City, as it still has not caused the maximum deterrent effect for the community in Kota Langsa. So there are always new actors to maisir action. Therefore, this research is to know the effectiveness of punishment for gamblers in Langsa City and to know the obstacle to punishment for gamblers in Langsa City.
\end{abstract}

Design/Methodology/Approach - The type of research used in this study is empirical research.

Findings - The findings of law enforcement research have not been effective in enforcing law enforcement against gambling. At the level of investigation and investigation conducted by the police is often that the case of gambling is not disclosed or unchecked and no further handling efforts were undertaken in order to enforce the law. While WH, which is a special sharia police handling cases of jinayat law violations in Aceh, also do not have or qualify as PPNS. Similarly, the case of gambling always continues to exist in the midst of society and does not cause deterrent effect for people in Langsa City Aceh Province, Indonesia. Obstacles in punishment for gamblers in Langsa City consists of two factors namely law enforcement factors and community factors.

Limitations of Research/Implications - This study highlights the problem of the effectiveness of the implementation of Qanun Jinayat in the punishment of gamblers in Aceh, especially Langsa City. Then the legal awareness of the community in Langsa City of Aceh Province is also seen.

Practical Implications - The solution offered enhances the professionalism of police investigators' performance in Langsa City, provides human resources/Police Wilayatul Hisbah in Langsa City of Aceh Province as civil servant investigator, provides socialization of law on Qanun Jinayat to the people in Langsa City.

Originality/Value - Gambling case always continues to exist in the middle of society and does not cause a deterrent effect for people in Langsa City of Aceh Province Indonesia.

Keywords Effectiveness of punishment, gambling perpetrators

All papers within this proceedings volume have been peer reviewed by the scientific committee of the Malikussaleh International Conference on Multidisciplinary Studies (MICoMS 2017).

(C) Siti Sahara and Meta Suriyani. Published in the Emerald Reach Proceedings Series. Published by Emerald Publishing Limited. This article is published under the Creative Commons Attribution (CC BY 4.0) licence. Anyone may reproduce, distribute, translate and create derivative works of this article (for both commercial and non-commercial purposes), subject to full attribution to the original publication and authors. The full terms of this licence may be seen at http://creativecommons.org/ licences/by/4.0/legalcode

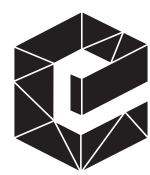

Emerald Reach Proceedings Series Vol. 1 


\section{Proceedings of 1 . Introduction}

MICoMS 2017 Aceh province in Indonesia makes rules that can regulate its people better, one of them as stated above is Qanun Aceh Number 13 Year 2003 about Maisir (Gambling), which currently is no longer valid and has been changed/replaced with Aceh Qanun Number 6 Year 2014 about the Jinayat Law. One of the goals of the exit of the Jinayat Qanun Law which regulates the Maisir (Gambling) is to prevent and overcome, meaning to make the original state and eliminate gambling evil because gambling is one of the criminal acts that disturb the community.

The resulting consequences not only disturb the public order, but the consequences are also greatly felt by the families of gamblers. Gambling often leads to other crimes such as liquor, theft, domestic violence, and fights. According to Article 1 point 22 of Qanun Aceh Number 6 Year 2014 on Jinayat Law, Maisir (gambling) is an act containing the element of betting and/or an element of chance made between two (two) parties or more, accompanied by the agreement that the winner will get paid/gain certain from the losers either directly or indirectly.

In Qanun Aceh Number 6 of 2014 on the Jinayat Code, it is affirmed that anyone who deliberately performs a Jarimah Maisir with a bet and/or profit of at most 2 (two) grams of pure gold is threatened with 'Uqubat Ta'zir whip at a maximum of 12 (twelve) times or a fine of not more than 120 (one hundred and twenty) grams of pure gold or a maximum of 12 (twelve) months imprisonment. Performing a Maari Jarimah with a bet value and/or gain of more than 2 (two) grams of pure gold is threatened with 'Uqubat Ta'zir whip at 30 (thirty) times or a fine of not more than 300 (three hundred) grams of pure gold or imprisonment maximum 30 (thirty) months. Organizing, providing facilities, or financing Jarimah Maisir is threatened with 'Uqubat Ta'zir whip at a maximum of 45 (forty-five) times and/or a fine of not more than 450 (four hundred and fifty) pure gold grams and/or a maximum of 45 fortyfive) months. Performing the Jarimah Maisir, involving children is threatened with 'Uqubat Ta'zir whip at a maximum of 45 (forty-five) times or a fine of not more than 450 (four hundred and fifty) pure gold grams or a maximum of 45 (forty-five) month. Conducting the Jarimah Maisir trial is subject to 'Uqubat Ta'zir at most 1/2 (half) of the threatened 'Uqubat'.

Uqubat Hudud and / or Ta'zir against anyone who commits deeds the actual gambling is felt to be ineffective in its implementation, because it is still has not caused the maximum deterrent effect for people in Langsa City. So that there are always new actors of maisir. Based on background the problem is how the effectiveness of punishment for the maisir perpetrator (gambling) in Langsa City and what are the obstacles to punishment for maisir perpetrators (gambling) in Langsa City.

\section{Literature review}

In the Encyclopedia of Islamic Law, it is explained that what maisir or maisir do is started at the time of Jahilliah known two forms of al-maisir, namely al-mukhatarah and at-tajzi'ah. In the form of al-mukhatarah, two men or more place their property and their wives as bets in a game. The person who won the game was entitled to take the treasure and the wife of the losing party. The treasure that belongs to the winner can be treated at will. If she likes her beauty, she will marry her, but if she does not like it, she takes him as a slave or concubine. This form is narrated by Ibnu Abbas (Dahlan, 1999).

There are several reasons why maisir is strictly prohibited in Islam:

(1) Economically, maisir can lead to poverty, because rarely happens someone constantly win, the most defeat. 
(2) Psychologically as the word Al-qur'an, gambling can cultivate curiosity and permusushan, and attitude ria, takabur, arrogant to the winner. While the losers can cause stress, depression, even lead to suicide.

(3) While sociologically, gambling can damage the family's kinship that is the core of society. Gambling also causes social conflicts such as divorce, arguments can even lead to criminal acts such as murder (Bakar and Halim, 2006).

According to Ahmad Wardi Muslich, Jarimah ta'zir is a finger threatened with ta'zir penalty. The meaning of ta'zir according to language is ta'dib, meaning giving lessons. Ta'zir is also interpreted by Ar-Raddu wal Man'u, which means refuse by preventing. The notion of ta'zir by term, as stated by Al-Mawardi is the following: Ta'zir is the punishment of education for sin (crime) which has not been determined by the shara (Muslich, 2008). Ta'zir is a term for punishment upon the fingers whose punishment has not been determined by the shara". Among fuqaha, jarimah-jarimah whose law has not been established by syara'dinamakan with jarimah ta'zir. Thus, the term ta'zir can be used for punishment and may also be for the finger (crime) (Muslich, 2008). The ta'zir's ordinances can actually be done with speech, such as denouncing, reminding strongly, and giving advice. Or, by deeds according to the conditions that demand them, such as by beating (culprit), imprisoning, handcuffing, expelling, and excommunication (Muslich, 2008).

\section{Methods}

The type of research used in this study is empirical research that searches primary data through field studies by interview, observation, and others. The data obtained, in the analysis by using a qualitative approach, namely an analysis, produces qualitative descriptive data.

\section{Findings}

\subsection{Primary question}

Ancient to modern times today maisir still remain sustainable and preserved by parties who like him. Even the development of the type/shape of maisir itself has been innovating from the times of its emergence. As the result of research conducted through observation and interview on Syar'iyah Langsa Court, it is known in Langsa City type/form as a tool for non criminal maisir used by players maisir various forms such as Joker Card, Domino Card, Game Online, Togel, Domino Stone, and Cock Saw (Abdul Latief, Head of Langsa Syariat Islam Service, 2017).

In Langsa City, locations are often found or the arrest of maisir perpetrators and still continue to be supervised on locations prone to maisir or other criminal acts such as: Sidodadi, Flow two, Karang Anyar, Lengkong, Alur Pinang, Bukit Rata, Blang Pase and Brawe Ground (Taufik Hidayat, Police Investigator Langsa, 2017). The age of the maisir actors is from 20 years to 60 years and the average of elementary to high school education. The work of most of the criminal offenders is unemployed, civil servant, entrepreneur, freelance laborer, trader, fisherman, pedicab driver, Mocok-mocok, and student/student (Reza, prosecutor of Langsa District Court, 2017).

Much of the work of maisir actors in Langsa City is from the middle to lower class. It is logically understandable that in general maisir actors are people who are risking fate or chancy. Where if win will take the form of goods/money at stake so that will increase income. This situation is caused by the need of life that is suffocating, lazy to try, and lack of sense of faith that exist in self maisir perpetrator. 
Proceedings of MICoMS 2017

\section{8}

In punishment of maisir crime in Langsa City, it can be based on the theory of Lowrence M. Friedman system, but it is grouped so that it is more narrowed that the law includes three components as follows:

(1) Legal substance: the rules, norms, and patterns of real human behavior within the system including the products produced by those within the legal system, including the decisions they make on the new rules they make.

(2) Legal structure (legal structure): is a framework, a persisting part, a section that provides some form and restriction to the whole law enforcement agencies. Indonesia is the structure of the legal system, among others; institutions or law enforcement agencies such as advocates, police, prosecutors, and judges.

(3) Legal culture (legal culture): is the mood of the system and the social forces that determine how the law is used, avoided or misused by the public (Jainah, 2011).

The punishment of gambling perpetrators in Langsa City, as understood from Legal substance, the punishment is based on Qanun Aceh Number 6 Year 2014 regarding Jinayat and Aceh Qanun Law Number 7 of 2013 on the Law of Jinayat Events, whereas previously the punishment is based on Qanun Aceh Number 13 Year 2003 on Maisir. The maisir perpetrator is on an average suspected and charged with Article 18 Qanun Aceh Number 6 Year 2014 regarding Jinayat Law, namely Every Person who intentionally performs the Jarimah Maisir with the value of wager and/or profit at most 2 (two) grams of pure gold, is threatened with 'Uqubat Ta'zir whip at most 12 (twelve) times or a fine of not more than 120 (one hundred and twenty) grams of pure gold or a maximum of 12 (twelve) months imprisonment. In terms of punishment for maisir perpetrators in Langsa City, the verdict handed down to the defendant maisir is' Uqubat Ta'zir which is whip about $6 \mathrm{~s} / \mathrm{d} 8$ times.

The Legal Structure (Qanun Hukum Hukum Jinayat) applies to law enforcement agencies and everyone in Aceh. Law enforcers against crime maisir in principle are not different from law enforcers who include Criminal Justice System in ordinary cases based on the Criminal Code or other National Provisions are Police, Public Prosecutors, Judges, and Public Institutions. Nevertheless, there is the addition of law enforcers in law enforcement jinayat in Aceh namely Police Wilayatul Hisbah. The Investigator is a Police Officer and Civil Service Investigator who has been authorized by law and/or Qanun to conduct an investigation. Investigators consist of (a) Police Officers and (b) Certain PPNS given special authority by law and/or Qanun, Officials: Police Officers, following the Police provisions, Investigator of Civil Servant, the lowest rank of the Young Designer, Group III/a or equivalent. The prosecutor is a functional official authorized by law to act as a public prosecutor and executive of a court decision that has obtained permanent legal force and other powers under the law.

Prosecution is the act of public prosecutor to delegate jinayat case to the Court of Syar'iyah which is authorized in matters and according to the manner stipulated in the Act and/or Qanun with the request to be examined and decided by the judge in the Court session. The Regency/City Syar'iyah Court is a first-level court institution. The Aceh Syar'iyah Court is an appellate court. The Supreme Court of the Republic of Indonesia hereinafter referred to as Mahmakah Agung is the cassation judicial institution. Police Wilayatul Hisbah, hereinafter referred to Police Police Wilayatul Hisbah is a member of Police Wilayatul Hisbah who function to socialize, supervise, enforcement, and guidance of the implementation of Islamic Sharia. In the case of the execution of the decision, the Public Prosecutor shall coordinate with the Police and the Office of the Islamic Sharia.

Based on the description of authority at the level of investigation and investigation conducted by the Police is often the case of gambling and is not disclosed or unchecked and 
no further handling efforts in order to enforce the law. While Police Wilayatul Hisbah who is a special sharia police handling cases of jinayat law violations in Aceh, also do not have or qualify as PPNS. So law enforcers have not been effective in implementing law enforcement.

Legal culture (legal culture) can be seen as in Table 1 convicted maisir perpetrators from years.

Based on Table 1, it can be seen from the results of research conducted on the case of gambling in every year in the Langsa Province Aceh Province, in 2015 amounted to 12 cases, in 2016 amounted to 15 cases and in 2017 amounted to 1 case and has executed the whip. However, from cases that have been tried and decided on the Syar'iyah Court, it is still very little compared with cases of gambling undetected by law enforcement (Dalfen, People of Langsa City, 2017). So the case of gambling always continues to exist in the midst of society and does not cause deterrent effect for people in Langsa City of Aceh Province Indonesia. Therefore, the punishment for maisir perpetrators (gambling) in Langsa City has not been.

\subsection{Second Question}

There are obstacles that are in fact still felt so that the punishment for gamblers in Langsa City has not been effective consisting of two factors namely law enforcement factors and community factors as follows:

(1) Law Enforcement Factors:

- The absence of human resources from the WH capacity/competent as a PPNS, so it cannot be independent in law enforcement.

- No further pursuit or investigation by the Investigator in the case of a person search list (DPO) if the suspect flees.

(2) Community Factors:

- The absence of awareness/compliance from the community not to violate Aceh Qanun Number 6 of 2014 on Jinayat Law. Seen that still exist every year consists of all jerder men and women and all ages i.e. adults, teenagers, and children.

\section{Discussion}

The factors causing the maisir crime (gambling) in Langsa City are as follows:

(1) Strangling life needs

(2) Fancy big gains from the game of gambling without having to work hard

(3) Lazy try/seek

(4) Carry out a hobby

(5) Lack of faith that exist in the maisir perpetrator

(6) The absence of awareness/compliance from the community not to violate Aceh Qanun Number 6 of 2014 on Jinayat Law.

\begin{tabular}{lrrr}
\hline Criminal Type & \multicolumn{3}{c}{ Case } \\
\hline Gambling & 2015 & 2016 & 2017 \\
& 12 & 15 & 1
\end{tabular}

Table 1.

Perpetrators of Gambling who have been convicted by Langsa Syari'ah Court 
Proceedings of The law enforcement of Maisir (Gambling) perpetrators in Langsa City is based on Qanun MICoMS 2017 Aceh Number 6 Year 2014 regarding Jinayat Law and Qanun Aceh Number 7 of 2013 on the Law of Jinayat Events, where previous punishment is based on Qanun Aceh Number 13 Year 2003 regarding Maisir. The maisir perpetrator is on an average suspected and charged with Article 18 Qanun Aceh Number 6 Year 2014 regarding Jinayat Law, namely Every Person who intentionally performs the Jarimah Maisir with the value of wager and/or profit

80 at most 2 (two) grams of pure gold is threatened with' Uqubat Ta'zir whip at most 12 (twelve) times or a fine of not more than 120 (one hundred and twenty) grams of pure gold or a maximum of 12 (twelve) months imprisonment. In terms of punishment for maisir perpetrators in Langsa City, the verdict handed down to the defendant maisir is' Uqubat Ta'zir which is whip about $6 \mathrm{~s} / \mathrm{d} 8$ times.

\section{Conclusion}

Law enforcers have not been effective in enforcing the law against gambling. At the level of the investigation and investigation conducted by the police is often the case of gambling and is not disclosed or unchecked and no further handling efforts in order to enforce the law. While $\mathrm{WH}$, which is a special sharia police handling cases of jinayat law violations in Aceh, also do not have or qualify as PPNS. Similarly, the case of gambling always continues to exist in the midst of society and does not cause a deterrent effect for people in Langsa City Aceh Province, Indonesia.

Obstacles in punishment for gamblers in Langsa City consist of two factors, namely law enforcement factors and community factors.

\section{References}

Bakar, A.A. and Halim, M. (2006). Islamic Criminal Law in Nanggroe Aceh Darussalam. Dinas Syari'at Islam Provinsi NAD, Banda, Aceh, pp. 75-76.

Dahlan, A.A. (1999). Encyclopedia of Islamic Law. PT Ichtiar Baru van Hoeve, Jakarta, p. 1053.

Jainah, Z.O. (2011). Building Law Enforcement Law Enforcement Community in Combating Narcotics Crime. Progressive Justice Vol. 2, No. September 2, p. 132.

Muslich, A.W. (2008). Islamic Criminal Law. Sinar Grafika, Jakarta, p. 12.

Qanun Aceh Number 7 of 2013 on the Law of Jinayat Events.

Qanun Aceh Number 6 Year 2014 on Jinayat Law.

Corresponding author

Siti Sahara can be contacted at sitisahara@unsam.ac.id 